\title{
Estimation of the source process
} and forward simulation of long-period grou $1 \mathrm{~d}$ motion of the 2018 Hokkaido Eastern I. . ' ri, Japan, earthquake

\author{
Hisahiko Kubo ${ }^{{ }^{*}}$ (D, Asako Iwaki ${ }^{1}$, Wataru Suzuki', Shin Aoi and Haruko Sekigyshi
}

\begin{abstract}
In this study, we investigate the source rupture process of the 2018 Hokka. Eascu In Iburi earthquake in Japan (M JMA 6.7) and how the ground motion can be reproduced using available source ar velocity models. First, we conduct a multiple-time-window kinematic waveform inversion using strong $n$ waveforms, which indicates that a large-slip area located at a depth of 25-30 km in the up-dip direction from the hypocenter was caused by a rupture propagating upward 6-12 s after its initiation. Moreover, the high-seisn icity area of aftershocks did not overlap with the large-slip area. Subsequently, using the obtained son deo del and a three-dimensional velocity structure model, we conduct a forward long-period $(<0.5 \mathrm{~Hz})$ ground-r. tion si ulation. The simulation was able to reproduce the overall ground-motion characteristics in the sedim antary ors of the Ishikari Lowland.
\end{abstract}

Keywords: The 2018 Hokkaido Eastern Iburi e? 'q q $\exists$ ke, Scurce process, Forward simulation, Long-period ground motion

\section{Background}

The 2018 Hokkaido Eastern Ibu earthquake (called "the 2018 Iburi earthquake" herea r) ocrurred in the eastern Iburi region of Hoklaido, Japun, at 3:08 JST on September 6, 2018 (18:08 U' Coptember 5, 2018) (Fig. 1a). The Japan Meteorolo cal Agency (JMA) magnitude $\left(M_{\mathrm{JMA}}\right)$ is 6.7 The mome at magnitude estimated from moment tenso. Research Instit te for b ty Science and Disaster Resilience (NIED' (I yama et al. 1998) and that obtained by the Glchal cent $1 /$ moment tensor (GCMT) Project are 6.6 and 6.7 , respectively. The moment tensor solution of the spatial distribution of aftershocks in the this event was an east-dipping reverselit uno (rig. 1a and b). The earthquake resulted in st. ground motion over Hokkaido, with a maximum

\footnotetext{
*Correspondence: hkubo@bosai.go.jp

${ }^{1}$ National Research, Institute for Earth Science and Disaster Resilience, 3-1

Tennodai, Tsukuba, Ibaraki 305-0006, Japan

Full list of author information is available at the end of the article
}

seismic intensity of 7 on the JMA scale and a maximum peak ground acceleration of approximately $1800 \mathrm{~cm} / \mathrm{s} / \mathrm{s}$. The earthquake caused severe damage by strong ground motion and coseismic landslides. Overall, more than 40 people were killed, more than 700 people were injured, and more than 2000 houses were partially or completely destroyed (FDMA 2019).

The center of the island of Hokkaido, where the source area of this earthquake is located, features the Hidaka collision zone, an arc-arc type collision zone between the northeast Japan arc and the Kuril forearc (e.g., Kimura 1996; Kita et al. 2010, 2012). Kita et al. (2012) revealed that beneath the Hidaka collision zone, a low-velocity zone having seismic velocities of crust materials exists in the mantle wedge of the continental plate (the North American Plate) and makes direct contact with the upper surface of the subducting oceanic plate (the Pacific Plate). In the crust beneath the Hidaka collision zone, many earthquakes have occurred, including two recent large reverse-fault-type earthquakes: the 1970 Hidaka earthquake $\left(M_{\mathrm{IMA}} 6.7\right)$ and the 1982 Urakawa-oki earthquake 


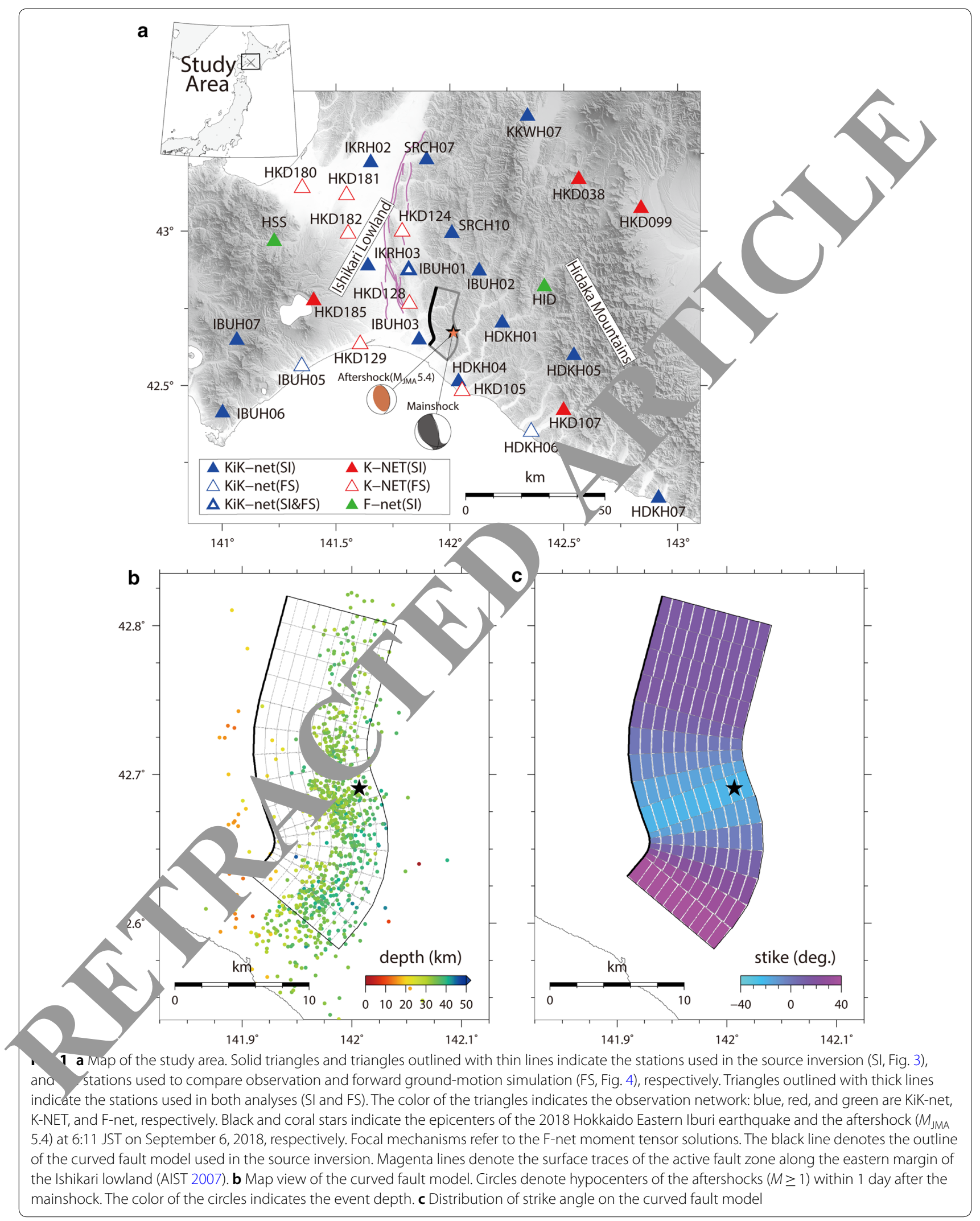


$\left(M_{\mathrm{IMA}}\right.$ 7.1). The crustal earthquakes within the continental plate have occurred at greater depths compared to ordinary ones in land in the Japanese Islands (HERP 2019). The 2018 Iburi earthquake with a hypocentral depth of approximately $35 \mathrm{~km}$ and the subsequent aftershocks also occurred within the crust of the continental plate.

In the conventional framework of strong-motion prediction in Japan, limited attention has been paid to relatively deep crustal earthquakes within the continental plate like the 2018 Iburi earthquake. Therefore, to strengthen the strong-motion prediction methodology, it is important to understand how the rupture of the 2018 Iburi earthquake initiated, grew, and terminated, as well as how the ground motion produced by this earthquake can be simulated using available source and velocity structure models. In this study, we approach these issues using ground-motion records observed by the nationwide strong-motion networks, K-NET and KiK-net, and deployed and operated by NIED (e.g., Aoi et al. 2011; NIED 2019b). We first estimate the source process of the event from strong-motion waveforms using a multiple-time-window kinematic waveform inversion. Ther, using the obtained source model together with a tha dimensional (3-D) velocity structure model, we corduct a forward simulation of long-period $(<0.5 \mathrm{~Hz}$ orc und motion and compare the result of the simulat in the observations, especially in the Ishikari Lo ${ }^{1}$ and. Du, ig the 2003 Tokachi-oki earthquake $\left(M_{\mathrm{IMA}} 8.0\right.$, ignificant long-period ground motion was obs-1ved in thy ishikari Lowland, and the ground-motior characteristics were investigated using a forward wave $\mathrm{m}$ simulation (e.g., Hatayama et al. 2007; Aoi et al. 2008).

\section{Source inversion}

\section{Data, fault model, and'me od}

The source process a d using a multiple-timewindow linear kinema waveform inversion methodology explair ea detail by Sekiguchi et al. (2000) and Suzuki et al. (20 who followed the approaches of Olson a 1d Apsel (1982) and Hartzell and Heaton (1983).

$\mathrm{We}_{4}$ stro g-motion waveforms at 20 stations (Fi a): 1 K-net stations in borehole, 4 K-NET staons in oround surface, and 2 F-net (Okada et al. 2004; N. 2019a) stations in vault. At the F-net stations, we use a a observed by velocity-type strong-motion seismographs. Although three components of the seismogram are used at most of the stations, only the horizontal components are used at IBUH03, because the data of the up-down seismograph in the borehole had some problems at the time of the mainshock. Except for data from the F-net stations, where original data are velocity waveforms, the original acceleration waveforms are numerically integrated in the time domain into velocity. The velocity waveforms are band-pass filtered between 0.05 and $0.5 \mathrm{~Hz}$, resampled to $5 \mathrm{~Hz}$, and windowed from $1 \mathrm{~s}$ before $\mathrm{S}$-wave arrival for $25 \mathrm{~s}$.

The spatial distribution of the aftershocks shows that the strike angle of the earthquake graa $11, \mathrm{ch}$ nged along the strike direction (Fig. 1b). This indica t/at it is unreasonable to express the source ult of this event by a single rectangular plane. Cons que. we we a more realistic fault model in the sor rce invers 1 . Based on the spatial distribution of the a rshocks and the moment tensor solution of F-net e de an curved fault model that is approximated by tiple rectangular subfaults (Fig. $1 \mathrm{~b}$ and c). Th curved a it model is described by multiple planes, ach th a width of $20 \mathrm{~km}$, a top depth of approximat $22 \mathrm{~km}$, $\mathrm{nd}$ a dip angle of $65^{\circ}$, and various strike gle The dip angle is based on the F-net moment tens soluuon. The assumed strike angle of the planes changes 8 dually along the strike direction: $15^{\circ}$ in the nor the $-20^{\circ}$ in the central part, and $40^{\circ}$ in the souther part (Fig. 1c). The rupture starting point is set at $42.690 \mathrm{~N}, 142.0067^{\circ} \mathrm{E}$, at a depth of $37.04 \mathrm{~km}$, which the hypocenter determined by JMA. The fault model is livided into 15 rectangle subfaults along the strike di.ection and 10 subfaults along the dip direction. The maximum subfault size is $2 \times 2 \mathrm{~km}$. The top and bottom lengths of the fault model are approximately $22.2 \mathrm{~km}$ and $25.4 \mathrm{~km}$, respectively. The total area of the fault model is approximately $476.6 \mathrm{~km}^{2}$. At an extension of the fault model along the up-dip direction, there exists the active fault zone along the eastern margin of the Ishikari Lowland extending in an NS direction (Fig. 1a); however, the assumed dip angle of this active fault is low at depths greater than $3 \mathrm{~km}$ (HERP 2010), which is inconsistent with the high dip angle of this earthquake (65 in F-net).

The slip time history of each subfault is discretized using eight smoothed ramp functions (time-windows) progressively delayed by $0.4 \mathrm{~s}$, and having a duration of $0.8 \mathrm{~s}$ each. The number of time-windows is determined using a trial-and-error process, so that the source time function at each subfault can be explained properly. The first time-window starting time is defined as the time prescribed by a circular rupture propagation of constant speed, $V_{\mathrm{ftw}}$. Hence, the rupture process and seismic waveforms are linearly related via Green's functions. The slip within each time-window at each subfault is derived by minimizing the difference between the observed and synthetic waveforms using a least-squares method. To stabilize the inversion, the slip angle is allowed to vary within $\pm 45^{\circ}$ centered at $107^{\circ}$, which is the rake angle of the F-net moment tensor solution, using the non-negative least-squares scheme (Lawson and Hanson 1974). In addition, we impose a spatiotemporal smoothing 
(See figure on next page.)

Fig. 2 a Map projection of the total slip distribution. The slip contour interval is $1.0 \mathrm{~m}$. The star denotes the epicenter. Gray circles denote the hypocenters of the aftershocks $(M \geq 1)$ that occurred within 1 day after the mainshock. The size of the circles indicates the event magnitude. Dotted lines denote the isodepth contours of the curved fault model at $5 \mathrm{~km}$ intervals. b Rupture progression in terms of slip amount for each $2.0 \mathrm{~s}$ interval. The slip contour interval is $0.8 \mathrm{~m}$. c Comparison of observed waveforms in the mainshock (red) and the M MAA 5.4 aftershock (black) at/10 K H04 and IBUH01. These waveforms, which were observed on the ground surface, are low-pass filtered at $0.5 \mathrm{~Hz}$

constraint on slips (Sekiguchi et al. 2000). The weight of the smoothing constraint is determined based on Akaike's Bayesian Information Criterion (Akaike 1980).

Green's functions are calculated using the discrete wavenumber method (Bouchon 1981) and the reflection/ transmission matrix method (Kennett and Kerry 1979) with a one-dimensional (1-D) layered velocity structure model. The 1-D velocity structure models are obtained for each station from the 3-D velocity structure model (Fujiwara et al. 2009). Logging data is also referred to for the KiK-net stations. Although a 1-D structure model used for calculating Green's functions differs among stations, the models have a common structure at depth deeper than $13 \mathrm{~km}$ where the assumed fault model is located. To consider the rupture propagation effect in each subfault, 25 point sources are uniformly distribut $d$ over each subfault to calculate the Green's functions (e.q Wald et al. 1991). For stations near the fault (I5, H02, HDKH01, HDKH04, IBUH03, and IBUH01), w/ hts that are two times larger than those for the othe statio are used.

\section{Results and discussion}

Figure 2a, b shows the total slip di tribution of the 2018 Iburi earthquake by map projection $d$ the rupture progression, whereas Additiona file 1: rigures S1 and S2 show the total slip distribution $\mathrm{D}$. Mar projection and the slip-velocity time fivtion (r each subfault. The seismic moment is $2.910^{1} \mathrm{Nm}\left(\Lambda_{\mathrm{w}} 6.9\right)$, which is larger than those estimaten r-net and GCMT $\left(1.0 \times 10^{19}\right.$ $\mathrm{Nm}$ and $1.2 \times 0^{19} \mathrm{Nm}$, gne likely reason for this is that a portic 1 on in in the source model are derived to reproduce some par of later phases which are produced by the teinl heterogeneity of the actual velocity structure ana ich annot be fully reproduced with the 1-D ve y stru are model. One way to approach this issue fur alibration of the velocity structure model for Gh 's functions. The maximum final slip is $4.8 \mathrm{~m}$. $V_{\mathrm{ftw}}$ is set, $01.3 \mathrm{~km} / \mathrm{s}$, providing the smallest misfit solution among all solutions for $V_{\mathrm{ftw}}$ varying from 0.8 to $4.0 \mathrm{~km} / \mathrm{s}$. The large slips are mostly found at $25-30 \mathrm{~km}$ depth in the up-dip direction from the hypocenter. The horizontal extent of this large-slip area along the strike direction is approximately $10 \mathrm{~km}$. During the first $6 \mathrm{~s}$, the rupture slowly grows around the hypocenter with small slips. Subsequently, the rupture develops with a large moment release between $6 \mathrm{~s}$ and $12 \mathrm{~s}$ in $\mathrm{t} / \mathrm{large}-\mathrm{sin}$ area. The total rupture duration is approxi-tate $\mathrm{I}_{\mathrm{i}} \mathrm{s}$

The slow rupture growth $\mathrm{d}$ (ring the in, fial moment of this earthquake is supported the observed waveforms. Figure 2c shows the $y$ for corded at HDKH04 and IBUH01 during cire $\mathrm{m}$ shock and of an $M_{\mathrm{IMA}} 5.4$ aftershock that or. red at 6,1 on September 6, 2018 (JST). The latter occ ed near the mainshock hypocenter (Fig. 1a, nd its t, cal depth $(37.67 \mathrm{~km})$ is practically the $s$ a of the mainshock. This waveform comparison "cates that although the shape of the main wave of ne mainshock is similar to that of the aftershocr main phases of the mainshock arrived several sconds later than those of the aftershock. This suggests that the radiation of seismic waveforms was not nificant during the initial moment of this earthquake, wi ch is consistent with the source model derived in this ady.

Figure 2a shows the spatial distribution of the aftershocks as well as the total slip distribution. Most aftershocks occurred at a depth of approximately $30-35 \mathrm{~km}$, whereas only a few aftershocks occurred within the large-slip area. This pattern has also been noted in other crustal earthquakes such as the 1992 Landers earthquake (e.g., Cohee and Beroza 1994), the 1995 south Hyogo (Kobe) earthquake (e.g., Ide et al. 1996), the 1999 ChiChi earthquake (e.g., Wu et al. 2001), the 2002 Denali earthquake (e.g., Asano et al. 2005), the 2016 Kumamoto earthquakes (e.g., Kubo et al. 2016), and the 2016 Central Tottori earthquake (e.g., Kubo et al. 2017).

Figure 3 shows a comparison between the observed and synthetic waveforms. The waveform fit is satisfactory.

\section{Forward ground-motion simulation Method and velocity structure model}

To evaluate how the ground motion of the earthquake can be reproduced by the current available source and velocity models, we carry out a forward ground-motion simulation at frequencies $<0.5 \mathrm{~Hz}$. We use the 3-D finitedifference method with discontinuous grids (Aoi and Fujiwara 1999; Aoi et al. 2004), in which the grid size is set to $80 \mathrm{~m}$ in both the horizontal and vertical directions at depths shallower than $10 \mathrm{~km}$, and three times greater at larger depths.

For the forward simulation, we use the aforementioned source model. For the velocity structure model, 


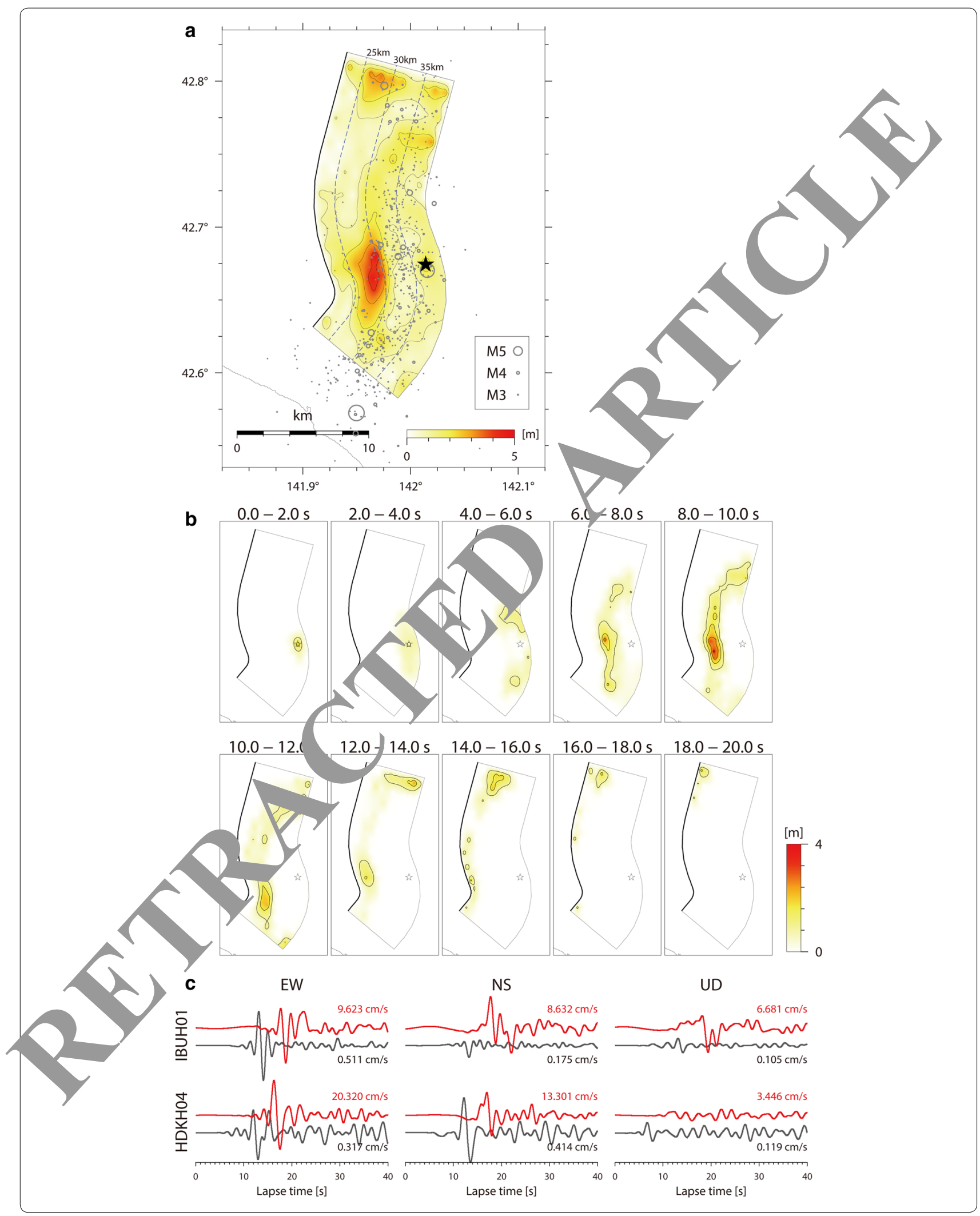




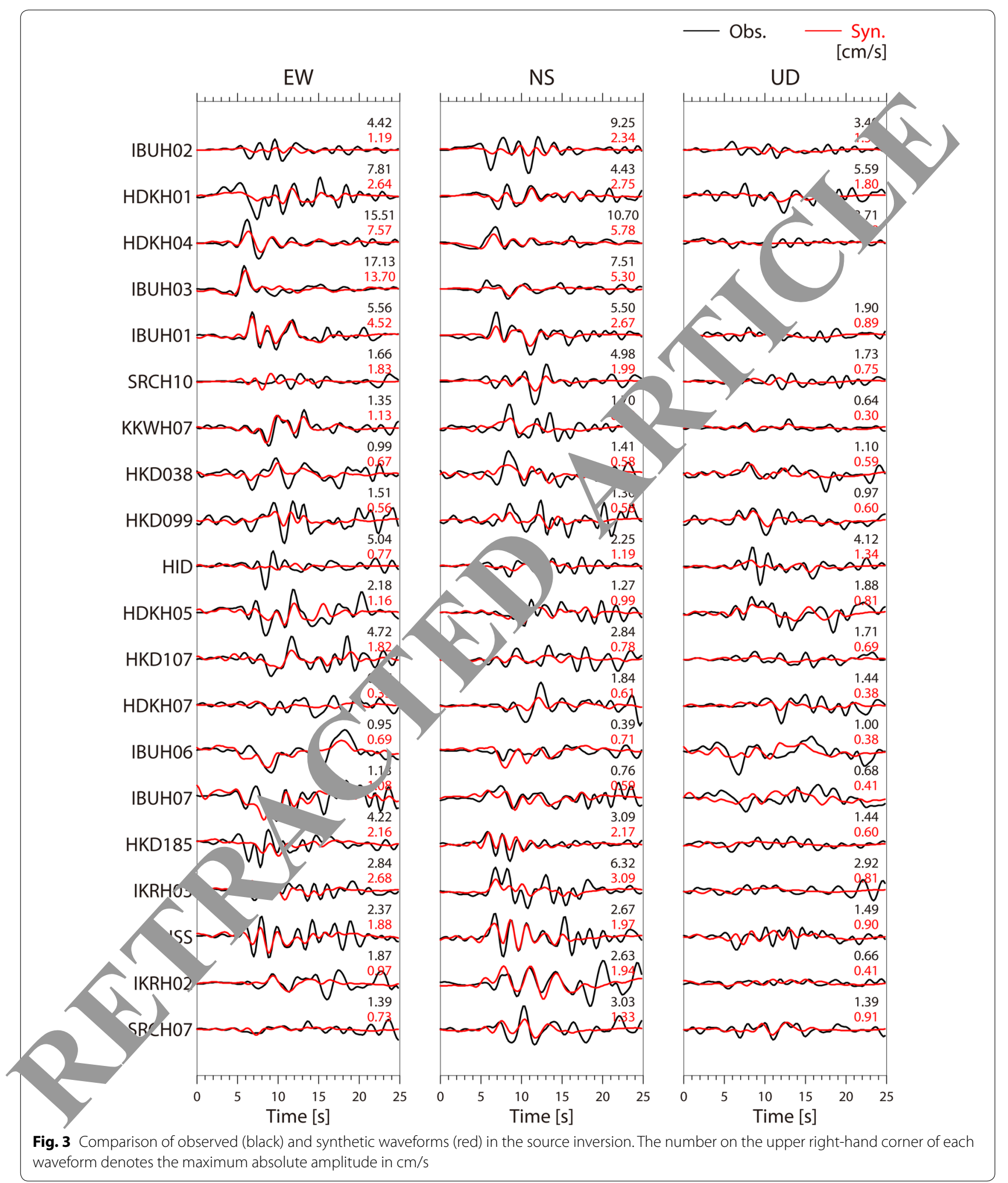

J-SHIS v2 3-D velocity model (Fujiwara et al. 2009, 2012), which covers the deep subsurface structure from the engineering bedrock $\left(V_{\mathrm{S}}=600 \mathrm{~m} / \mathrm{s}\right)$ to the upper crust
$\left(V_{\mathrm{S}}=3400 \mathrm{~m} / \mathrm{s}\right)$, is connected to the lower crust structure $\left(V_{\mathrm{S}}=3700 \mathrm{~m} / \mathrm{s}\right)$ that is consistent with the 1-D structure model used in the slip inversion. Additional file 1: 
Figure S3 shows the structure of the seismic bedrock and selected layers of J-SHIS deep subsurface velocity model. The seismic bedrock reaches a depth of approximately $10 \mathrm{~km}$ in the region west of the Hidaka Mountains, forming the Ishikari Lowland. The low-velocity layers of Late Miocene to Pliocene $\left(V_{\mathrm{S}}\right.$ of approximately $700-1100 \mathrm{~m} / \mathrm{s}$ ) are distributed in a north-south direction west of the source fault.

To validate the performance of the velocity structure model, we first conduct a ground-motion simulation for the $M_{\text {JMA }} 5.4$ aftershock (Fig. 1a), assuming a doublecouple point source with the mechanism and the seismic moment referring to F-net, and a smoothed ramp-type source time function with a 2-s duration. This groundmotion simulation agrees reasonably with the observed ground motion in terms of the velocity waveforms, in the amplitudes of both the direct S-wave pulse and later phases (Additional file 1: Figure S4), which implies the appropriateness of the assumed 3-D velocity structure model. The distribution of the peak ground velocity (PGV) is also consistent with the observations, except for the region near stations HKD 129 and HKD180 where the simulation underestimated the observations (Add; tional file 1: Figure S5). Note that in this section, we waveforms observed on the ground surface (K-NF/ ana ground-surface seismograph of KiK-net) which re $r o m$ pared with the simulated waveforms at the nging bedrock $\left(V_{\mathrm{S}}=600 \mathrm{~m} / \mathrm{s}\right)$. The effect of site implifica on from the engineering bedrock to the g oun curface is assumed to be small, as all waveforn are low $p$ ass filtered at $0.5 \mathrm{~Hz}$, although this ma not be the case for several stations as discussed later. he PGY in the area around the epicenter is small in con to other areas such as the Ishikari Lowland, this area is located along the node of the S-wave radiation pattern for the aftershock mechanis iso tion ( Fig. 1a), that is, the minimum direction of 5 van.

\section{Results and i'scu. in}

Figure 4 nows the nulated velocity waveforms of the $2018 \mathrm{~J}$ ri arthquake in comparison to the observed wavefor at sclected stations within and around the Isili $i$ Low and, along the southern coast of the study a ${ }^{2}$ 06, HKD105, IBUH05, and HKD129), anc orth of the fault (HKD128, IBUH01, HKD124, HKD , 82, HKD181, and HKD180) (Fig. 1a). Although the amplitudes of the simulated waveforms are relatively smaller than those of the observed waveforms at most stations, the shape of the S-wave in the simulation is close to that in the observations. The arrival times of the distinctive later phases, which arrive after the $\mathrm{S}$-wave, are consistent with the observations at many stations in the Ishikari Lowland; for instance, at HKD181 at around $\mathrm{t}=40-55 \mathrm{~s}$, in the horizontal directions, this consistency is observed (see gray bars in Fig. 4). This suggests that the generation of surface waves in the sedimentary layers could be reproduced by the 3-D wave-propagation simulation $r$, at stations HKD129 and HKD180, the amplit. of the later phases were remarkably unr restimated, as they were for the simulation of tho $M_{1}, 5.4$ aftershock (Additional file 1: Figure A4), suggest o that the site response of the shallow su surface) structure around these areas, which is at c ide ed in our simulation, may not be negl gib ven in this frequency range $(<0.5 \mathrm{~Hz})$.

The spatial dis ribu $n$ of the PGV, or the maximum amplitude of vecto, sum of the three-component velocity wo refor ns. is shown in Fig. 5. The simulated PGV distrib seismic bedroc Additional file 1: Figure S3), suggesting than $\mathrm{GV}^{2}$ is amplified by the deep subsurface structur. The simulated PGV tends to be consistent with the observations at epicentral distances longer nn approximately $40 \mathrm{~km}$, while it tends to be underes mated at shorter distances. Underestimation of the PQ $A$ near HKD180 appears both for the mainshock and ine $\mathrm{M}_{\mathrm{JMA}} 5.4$ aftershock (Additional file 1: Figure S5), again suggesting the need for considering site responses by the shallow subsurface structure.

The forward waveform simulation of the mainshock, which is presented here, shows that although the overall feature of the observations is reproduced, the amplitude is underestimated. Considering the simulation results of the aftershock in which the observed amplitude was well reproduced at most stations (Additional file 1: Figures S4 and S5), this result indicates that although the assumed 3 -D velocity structure model and the overall feature of the input source model are appropriate, the details in the source model are insufficient. This implies a need for (1) improvement of the source model using the calibration of the velocity structure model for Green's functions, and (2) refinement of the fault model.

In this study, we focused on modeling ground motion at frequencies lower than $0.5 \mathrm{~Hz}$. In future work, it is important to target broadband ground motion to explain the strong ground motion with high seismic intensity (7 as the maximum in JMA scale); this will require precise analysis of the site responses by the shallow subsurface structure. 


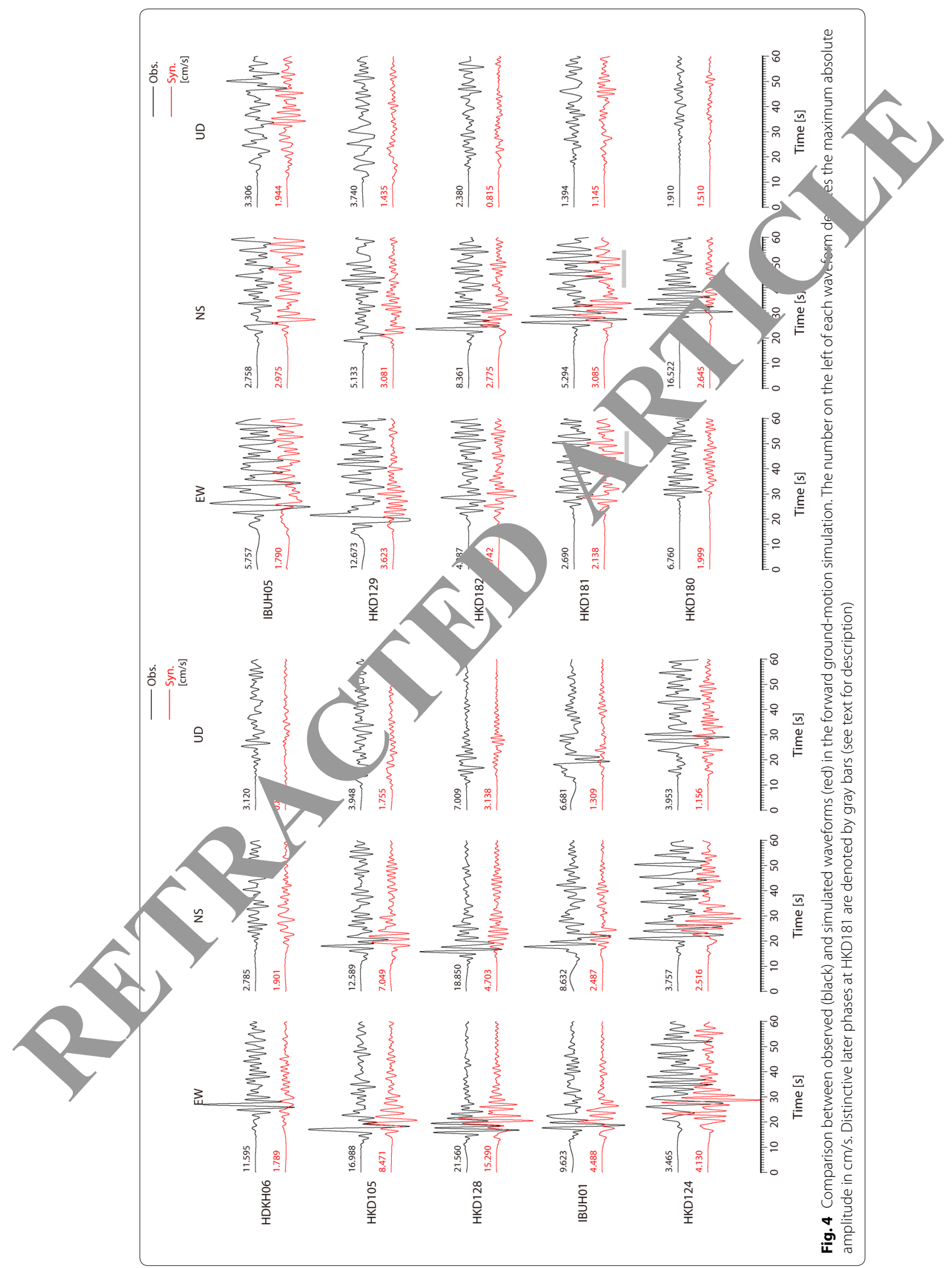




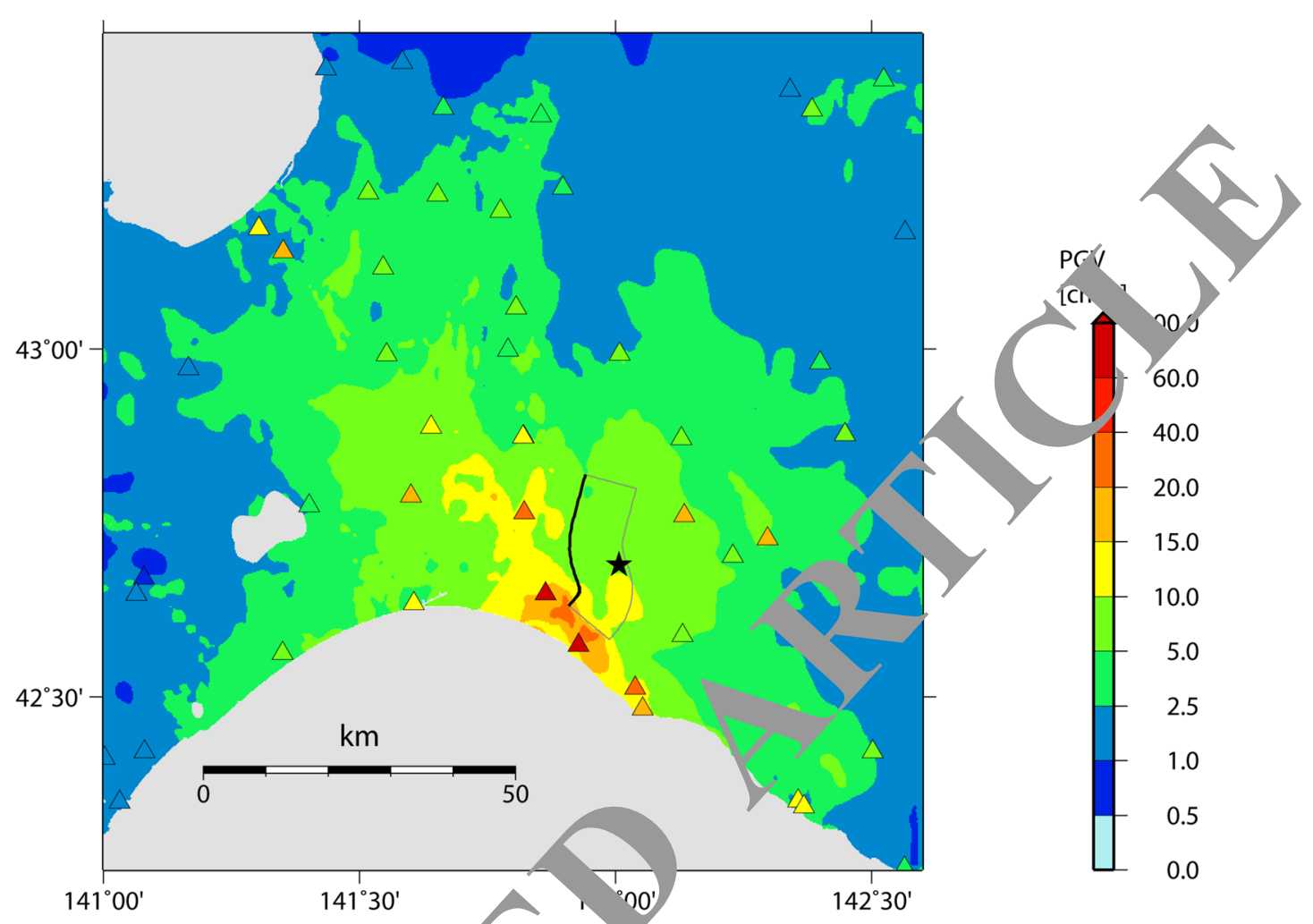

Fig. 5 Simulated PGV distribution. The PGV is the maximum absolute amph ade of the vector sum of the three-component velocity waveform low-pass filtered at $0.5 \mathrm{~Hz}$. The triangles denote the observea at K-N T and KiK-net stations for comparison

\section{Conclusions}

The 2018 Iburi earthquake was a relatively deep crustal earthquake within the continei ' plat that caused strong ground motion over n wide area of Hokkaido. Crustal earthquakes at such d punot accounted for in the current frameworl- of gro and-motion prediction in Japan. Therefore, un erst hding the rupture process and the ground motion cant for impro ing futu. predictions. To approach this aim, in this tua we conducted a source inversion and forward g, und-mo himulation.

The curce rupture process of the 2018 Iburi earthquake $w_{c}$ rst e cimated from strong-motion waveforms usine a in ciple-time-window kinematic waveform ver 4 -large-slip area with a maximum slip of $4.8 \mathrm{~m}$ wa sund at a depth of $25-30 \mathrm{~km}$ in the up-dip direction $1, \mathrm{om}$ the hypocenter. The estimated source model indicated that the rupture slowly grew around the hypocenter with small slips during the first $6 \mathrm{~s}$. Then, the rupture developed with a large moment release between $6 \mathrm{~s}$ and $12 \mathrm{~s}$ in the large-slip area. The large-slip area did not overlap with the high-seismicity area of aftershocks.

Using the obtained source model and the 3-D velocity structure model, J-SHIS v2, we conducted a forward ground-motion simulation in the frequency range of $<0.5 \mathrm{~Hz}$. Although the amplitudes were underestimated at most stations, the arrival times of the distinctive later phases were consistent with the observations at stations of the sedimentary layers of the Ishikari Lowland. The results of the simulation of the mainshock and the aftershock suggest that although the assumed 3-D velocity structure model and the overall feature of the input source model of the mainshock were appropriate, the details in the source model were insufficient to reproduce the observation of the mainshock.

\section{Supplementary information}

Supplementary information accompanies this paper at https://doi. org/10.1186/s40623-019-1079-6.

Additional file 1: Figure S1. Planar projection of the total slip distribution. The slip contour interval is $0.8 \mathrm{~m}$. The vectors denote the direction and amount of slip of the hanging wall side. The open star denotes the rupture starting point. Figure $\mathbf{S 2}$. Slip-velocity time function of each subfault. The star denotes the subfault corresponding to the rupture starting subfault. Figure S3. Maps showing some selected layers of the J-SHIS V2 3D velocity model. The triangles denote K-NET and KiK-net stations shown in the forward waveform simulation (Figs. 4 and 5). (a) Depth of the bedrock $\left(V_{S}=2900 \mathrm{~m} / \mathrm{s}\right)$, which reaches a depth of approximately $10 \mathrm{~km}$ west of the Hidaka Mountains. (b) Bottom interfaces 
of two selected low-velocity layers $\left(V_{S}=700 \mathrm{~m} / \mathrm{s}\right.$ and $1100 \mathrm{~m} / \mathrm{s}$ ) of Late Miocene to Pliocene, distributed in a north-south direction west of the Hidaka Mountains and the source fault. Figure S4. Comparison between observed (black) and simulated waveforms (red) in the forward ground motion simulation for the aftershock ( $M_{\text {JMA }}$ 5.4) at 6:11 JST on September 6,2018 . The number on the left of each waveform denotes the maximum absolute amplitude in $\mathrm{cm} / \mathrm{s}$. Figure $\mathbf{S 5}$. Simulated PGV distribution for the aftershock ( $M_{\text {JMA }}$ 5.4) at 6:11 JST on September 6, 2018. The PGV is the maximum absolute amplitude of the vector sum of the three-component velocity waveforms low-pass filtered at $0.5 \mathrm{~Hz}$. The triangles denote the observed PGV at K-NET and KiK-net stations for comparison.

\section{Abbreviations}

JMA: Japan Meteorological Agency; NIED: National Research Institute for Earth Science and Disaster Resilience; 3-D: three-dimensional; 1-D: one-dimensional; PGV: peak ground velocity.

\section{Acknowledgements}

We thank Associate Prof. N. Takai, the editor, and two anonymous reviewers for their helpful comments. We used the unified hypocenter catalog provided by JMA and the 10-m mesh DEM published by the Geospatial Information Authority of Japan. We used Generic Mapping Tools (Wessel and Smith 1998) to draw the figures.

\section{Authors' contributions}

$\mathrm{HK}$ and $\mathrm{Al}$ analyzed the data, interpreted the results, and drafted the manuscript. WS, SA, and HS participated in the design of the study and the interpretation of the results. All authors read and approved the final manuscript.

\section{Funding}

Not applicable.

\section{Availability of data and materials}

The waveform records at K-NET and KiK-net (NIED 2019b) and r-ne 2019a) are available at the websites: http://www.kyoshin.bo ai.go.jp/an http://www.fnet.bosai.go.jp/. The data sets used during t/ $/ 6$ rent study).re available from the corresponding author on a reasonab. re

\section{Competing interests}

The authors declare that they have no competir interests.

\section{Author details}

${ }^{1}$ National Research, Institute for Earth Sc and Disaster Resilience, 3-1 Tennodai, Tsukuba, Ibaraki 305-0006, Japal. Prevention Research Institute, Kyoto University, Gokasho Uji, Kyc+ 61120011 , Japan.

Received: 1 March 2019 pte 2019

Published online: 18 Septo er 2019

\section{References}

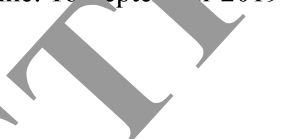

AIST (Nati hal Mnstitute of Advanced Industrial Science and Technology) (200\% ve faul database of Japan, December 13, 2007 version. AIST, Taukuba

A'aike (1980) Llihood and the Bayes procedure. In: Bernardo JM, De ress, varencia, pp 143-166

Aoi S, Wara H (1999) 3D finite-difference method using discontinuous grias. Bull Seism Soc Am 89:918-930

Aoi S, Hayakawa T, Fujiwara H (2004) Ground motion simulator: GMS. BUTSURITANSA 57:651-666 (in Japanese with English abstract)

Aoi S, Honda R, Morikawa N, Sekiguchi H, Suzuki H, Hayakawa Y, Kunugi T, Fujiwara H (2008) Three-dimensional finite difference simulation of longperiod ground motions for the 2003 Tokachi-oki, Japan, earthquake. J Geophys Res 113:B07302. https://doi.org/10.1029/2007JB005452

Aoi S, Kunugi T, Nakamura H, Fujiwara H (2011) Deployment of new strong motion seismographs of K-NET and KiK-net, in earthquake data in engineering seismology. Geotechnol Geol Earthquake Eng 14:167-186. https://doi.org/10.1007/978-94-007-0152-6_12

Asano K, Iwata T, Irikura K (2005) Estimation of source rupture process and strong ground motion simulation of the 2002 Denali, Alaska, earthquake. Bull Seismol Soc Am 95(5):1701-1715

Cohee BP, Beroza GC (1994) Slip distribution of the 1992 La rats earthquake and its implications for earthquake source $m$ chat ics. Bull Seismol Soc Am 84(3):692-712

FDMA (Fire and Disaster Management Agency) (2019) The 2 kaido Eastern Iburi earthquake (34th report/. http://www.ly na.go.jp/ bn/2018/detail/1074.html. Accessed 18 Mc 019 (in Jo nahese)

Fujiwara H, Kawai S, Aoi S, Morikawa N, Sen S, Ku V, Od, M, Hao KX, Hayakawa Y, Toyama N, Matsuyame A, Iwamoto n, Zzuki H, Liu Y (2009) A study on subsurface stru ure model fordeep sedimentary layers of Japan for strong-motion Juation. Natl Res Inst for Earth Sci Disaster Prev 337:260 (in J? nese,

Fujiwara H, Kawai S, Aoi S, Mcrikam Senna S, Azuma H, Ooi M, Hao KX, Hasegawa N, Maeda T iwaki A, Vh matsu K, Imoto M, Okumura T, Matsuyama H, Nari a 012) Some Improvements of seismic hazard assessment basea on th 11 Tohoku earthquake. Natl Res Inst for Earth Sci Disa - Prev 379: - 49 (in Japanese)

Fukuyama $\mathrm{E}$, Ish da $\mathrm{M}$; reger $\mathrm{DS}$, Kawai $\mathrm{H}$ (1998) Automated seismic moment or ation by using on-line broadband seismic waveforms. J 'm Soc Jpn (Zisin 2) 51:149-156

Hartzell SH, Heaton i. 983) Inversion of strong ground motion and telese aveforth data for the fault rupture history of the 1979 Imperial Valley u, ornia, earthquake. Bull Seismol Soc Am 73(6):1553-1583

Hatayama Kanno T, Kudo K (2007) Control factors of spatial variation of Kg-period strong ground motions in the Yufutsu sedimentary basin, Hokkaido, during the $M_{\mathrm{w}} 8.02003$ Tokachi-oki, Japan, earthquake. Bull Seismol Soc Am 97:1308-1323. https://doi. org/10.1785/0120060200

P (Headquarters for Earthquake Research Promotion) (2010) Partial revision of long-term evaluation of the Ishikari-teichi-toen fault zone. https ://www.jishin.go.jp/main/chousa/katsudansou_pdf/06_ishikari-teich i_2.pdf. Accessed 18 May 2019 (in Japanese)

HERP (Headquarters for Earthquake Research Promotion) (2019) Evaluation of the 2018 Hokkaido Eastern Iburi Earthquake. https://www.jishin.go. jp/main/index-e.html. Accessed 18 May 2019 (in Japanese)

Ide S, Takeo M, Yoshida Y (1996) Source process of the 1995 Kobe earthquake: determination of spatio-temporal slip distribution by Bayesian modeling. Bull Seismol Soc Am 86(3):547-566

Kennett BLN, Kerry NJ (1979) Seismic waves in a stratified half space. Geophys J Int 57:557-583

Kimura G (1996) Collision orogeny at arc-arc junctions in the Japanese Islands. Is Arc 5:262-275

Kita S, Okada T, Hasegawa A, Nakajima J, Matsuzawa T (2010) Anomalous deepening of a seismic belt in the upper-plane of the double seismic zone in the Pacific slab beneath the Hokkaido corner: possible evidence for thermal shielding caused by subducted forearc crust materials. Earth Planet Sci Lett 290:415-426. https://doi.org/10.1016/j. epsl.2009.12.038

Kita S, Hasegawa A, Nakajima J, Okada T, Matsuzawa T, Katsumata K (2012) High-resolution seismic velocity structure beneath the Hokkaido corner, northern Japan: Arc-arc collision and origins of the $1970 \mathrm{M}$ 6.7 Hidaka and 1982 M 7.1 Urakawa-oki earthquakes. J Geophys Res 117:12301. https://doi.org/10.1029/2012jb009356

Kubo H, Suzuki W, Aoi S, Sekiguchi H (2016) Source rupture processes of the 2016 Kumamoto, Japan, earthquakes estimated from strong-motion waveforms. Earth Planets Space 68:161. https://doi.org/10.1186/s4062 3-016-0536-8

Kubo H, Suzuki W, Aoi S, Sekiguchi H (2017) Source rupture process of the 2016 central Tottori, Japan, earthquake ( $M_{\text {JMA }} 6.6$ ) inferred from strong motion waveforms. Earth Planets Space 69:127. https://doi. org/10.1186/s40623-017-0714-3

Lawson CL, Hanson RJ (1974) Solving least squares problems. Prentice-Hall, Old Tappan

National Research Institute for Earth Science and Disaster Resilience (2019a) NIED F-NET, National Research Institute for Earth Science and Disaster Resilience. https://doi.org/10.17598/nied.0005 
National Research Institute for Earth Science and Disaster Resilience (2019b) NIED K-NET, KiK-net, National Research Institute for Earth Science and Disaster Resilience. https://doi.org/10.17598/nied.0004

Okada Y, Kasahara K, Hori S, Obara K, Sekiguchi S, Fujiwara H, Yamamoto A (2004) Recent progress of seismic observation networks in Japan: Hi-net, F-net, K-NET and KiK-net. Earth Planets Space 56:15-28

Olson AH, Apsel RJ (1982) Finite faults and inverse theory with applications to the 1979 Imperial Valley earthquake. Bull Seismol Soc Am 72(6A):1969-2001

Sekiguchi H, Irikura K, Iwata T (2000) Fault geometry at the rupture termination of the 1995 Hyogo-ken Nanbu earthquake. Bull Seismol Soc Am 90(1):117-133

Suzuki W, Aoi S, Sekiguchi H (2010) Rupture process of the 2008 IwateMiyagi Nairiku, Japan, Earthquake derived from near-source strongmotion records. Bull Seismol Soc Am 100(1):256-266. https://doi. org/10.1785/0120090043
Wald DJ, Helmberger DV, Heaton TH (1991) Rupture model of the 1989 Loma Prieta earthquake from the inversion of strong-motion and broadband teleseismic data. Bull Seismol Soc Am 81(5):1540-1572

Wessel P, Smith WHF (1998) New, improved version of Generic Mapping Tools released. EOS Trans Am Geophys Un 79:579

Wu C, Takeo M, Ide S (2001) Source process of the Chi-Chi ea unquake: a joint inversion of strong motion data and global positionir sys em data with a multifault model. Bull Seismol Soc Am 91(5):1128-1

\section{Publisher's Note}

Springer Nature remains neutral with regard o jurs tional caims in published maps and institutional affiliations.

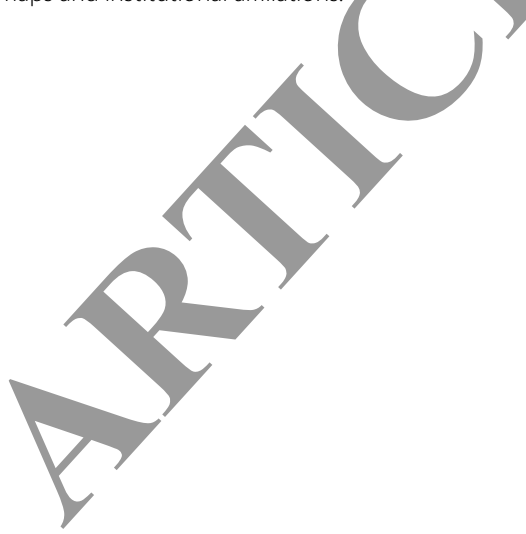

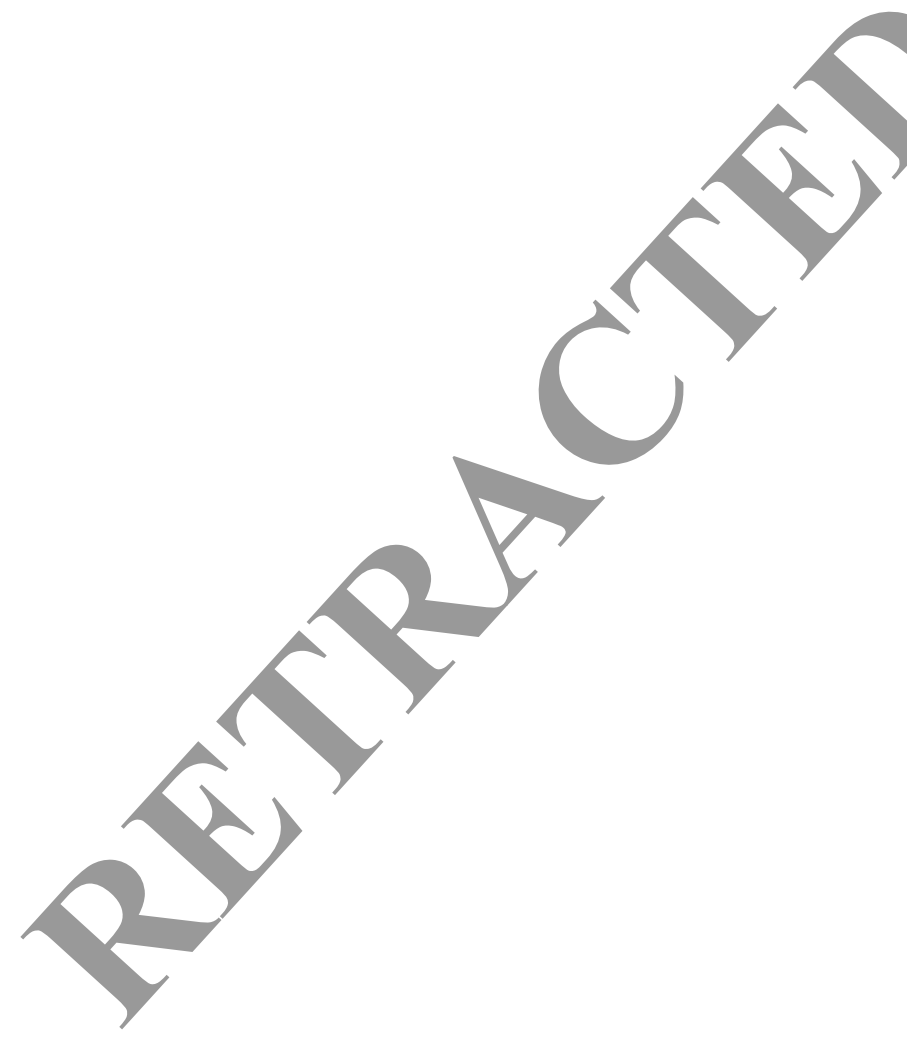

\section{Submit your manuscript to a SpringerOpen ${ }^{\circ}$ journal and benefit from:}

- Convenient online submission

$\checkmark$ Rigorous peer review

- Open access: articles freely available online

- High visibility within the field

- Retaining the copyright to your article

Submit your next manuscript at $\boldsymbol{\text { springeropen.com }}$ 